\title{
The relevance of financial information and contents of the new audit report for lending decisions of commercial banks
}

\author{
Marina Trpeska ${ }^{\mathrm{a}}$, Atanasko Atanasovski ${ }^{\mathrm{a}}$ and Zorica Bozinovska \\ Lazarevska, \\ ${ }^{a}$ University Ss Cyril and Methodius, Faculty of Economics-Skopje, \\ Macedonia
}

\begin{abstract}
This research study examines the importance of financial information and information contained in the ISA's New Audit Report effective from 2016 for lenders as capital providers. We base our findings on a survey conducted in September of 2016 with corporate loan officers for medium-large corporate clients in Macedonia. The results show that the annual report of the company, except for the management report and notes to the financial statements, has consistently high importance and usability for respondents' decision making. Various accounting ratios related to liquidity, financial stability and profitability of the company are considered very important and regularly used in credit analysis. However, respondents were not consistent in their shared perceptions regarding high importance of projected profits and historical information on operating cash flows. All loan officers gave high importance to the information found in existent auditor's report format regardless of the form of expressed opinion. Also, information on key audit matters, additional information on going concern and related auditor's judgement, procedures related to fraud risk were considered of high importance. Lenders rated as less important the disclosure of the name of engagement partner, auditor's statement on independence and compliance with ethical requirements and the level of materiality used in the audit.
\end{abstract}

${ }^{1}$ Corresponding authors: Department of Accounting and Audit, University Ss Cyril and Methodius in Skopje; Goce Delcev 9V, Skopje; tel. (+382) 23286 921; email addresses: marinas@eccf.ukim.edu.mk; atanasko@eccf.ukim.edu.mk; zoricab@eccf.ukim.edu.mk 
Keywords: importance of audit, new auditor's report, survey, lenders, lending decisions

\section{JEL codes: $M 41$}

\section{Introduction}

This study examines the importance and use of accounting information and accounting ratios for lending decisions, as perceived by corporate loan officers and heads of corporate loan departments. The study also focuses on perceived importance of information contained in the existent audit report format according to ISA's requirements and incremental information content of ISA's New Auditor's Report as effective from December, 2016.

The importance and usage of accounting information and accounting ratios in lending decisions is extensively investigated in the literature and remains an important topic in financial reporting since creditors as capital providers are considered key users of financial statements (Hines, 1982; Bartlett \& Chandler,1997; Berry \& Robertson, 2006). Researchers also reported changes in traditional importance of certain accounting information and accounting ratios over time, such as shifts from balance sheets and income statements to cash flow statements and increased use of projected financial statements and management accounts (Berry \& Robertson, 2006). One of the main motivations of our study was to investigate how traditional are banks in Macedonia in the use of accounting information for lending decisions and whether they tend to rely more on official and historical accounting information for reliability reasons or give more value to management projections and unaudited financial information.

Many researchers provided empirical evidence on the relevance of certain information in the audit report for the decision making of investors and creditors (Gay \& Schelluch, 1993; Miller et al., 1993; Bamber \& Stratton, 1997; Bartlett \& Chandler,1997; Berry \& Robertson, 2006; Guiral-Contreras et al., 2007). However, there were critics, both in academia and practice, on the usefulness of auditor's report for capital providers in dynamic business environment where entities are exposed to more risky and complex transactions.

The first big change of the audit report content was in 1993 as a result of the researches that bankers, analysts and shareholders confuse the relative responsibilities of management and auditors for the financial statements. There were a lot of misconceptions of the auditor's role and responsibilities. Some research studies provided evidence that bankers placed greater responsibility for the completeness and accuracy of the financial statements on auditors than on 
management (Nair \& Rittenberg, 1987). Bankers also felt in the past that audited financial statements were less reliable most likely because bankers were unfamiliar with the procedures employed by the independent auditors (Rankin, 1982). Even more, it was reported that the responsibility of the auditors is to prevent all major fraud and error (Gay \& Schelluch, 1993). Despite of these misconceptions and unfamiliar understandings of audit report in the very early years of audit report usage, accounting scandals in recent past and the world economic and financial crises have imposed larger importance for the audit profession.

The implications and usages of audit report are different in many areas of business environment. With the latest changes of ISA 700 and implementation of extended audit report, many questions were raised about its usefulness, its value added to different stakeholders and their decisions. The main purpose of our study was to evaluate perceptions of lenders about the importance of incremental information to be found in future audit reports in respect of, among the rest, key audit matters, going concern assumptions and material uncertainties, materiality used in the audit and procedures applied by auditor in respect of fraud in financial statements. We performed a survey among bank loan officers and heads of corporate loan departments involved in lending decisions with medium-large companies.

The results of the study show that historical accounting information and accounting ratios are very important for lending decisions in Macedonian banks. Loan officers give more importance to traditional and published financial information, in comparison to projected profits, historical cash flow information or the Management report part of the Annual report. Also lenders rely on information from the standard audit report, and gave equal importance weight to all types of auditor's opinion. Regarding the incremental information contained in the New Auditor's Report, lenders value most information on key audit matters, existence of material uncertainty and auditor's judgement for the going concern and auditor's procedures related to risk of fraud in the financial statements.

The reminder of the paper is structured as follows. The next section provides a literature review and presents the objective of the research and research hypotheses. The third section explains the research methodology, the empirical results are then presented, and a final section providing concluding remarks.

\section{Literature review}

Financial institutions loan millions of dollars to companies daily relying mainly on financial statements. This is one of the reasons why loan officers are considered among the principal users of financial information who are most affected by the credibility of audit reports and their interpretation in loan granting decisions (Guiral-Contreras et al., 2007). But bankers and loan officers reported different 
importance and usage of accounting information and audit report through the time. It is common conclusion from the academic papers, and practice too, that audited financial statements continue to be the most important single source of information for the lending decisions. Balance sheets and income statements are still important for credit analysis and loan decisions (Hines, 1982). Bartlett and Chandler (1997) highlighted shifts to cash flow statements as well as directors' report. Besides these changes in frequency of use of "traditional" statements and reports, there is noticed increased frequency of use of management accounts and projected financial statements (Berry \& Robertson, 2006). Also financial indicators have changed ranking and importance through the time. For example, profitability ratios are not any more the most important, but the prime importance is given to liquidity ratios in accordance with previous finding for increased importance of cash flow statement (Berry \& Robertson, 2006).

Long ago capital markets were not such developed like nowadays and independent auditor's report was significantly different from the one proposed in the latest ISA's. Up until now, it can be argued that standardized and predefined wording was used. Many researchers investigated the usefulness of the standard form of the audit report (Milleret al., 1993; Gay \& Schelluch, 1993). According to Epstein and Pava (1992) the auditors' report is considered more important than it used to be, but according to other researchers there is decreasing importance or extend of reading of the audit report despite the fact that it was considerably extended in 1993 (Anderson \& Epstein,1995; Bartlett \& Chandler,1997; Berry \& Robertson, 2006). The explanation for decreased importance of audit report could be found in increased complexity in accounting and audit profession that makes audit reports and published financial statements difficult for understanding outside the profession, for people such as loan officers.

The main changes in the current audit report were in 1993 when SAS600 (later on in 2004 replaced with ISA700) was primarily focused on identifying responsibilities of the management and the auditor (Masters, 2015). In this audit report introductory paragraph is included which specifically addresses relative responsibilities of management and auditors. Also, the scope paragraph of this audit report from 1993 was expanded to include a brief description of an audit and terms like "reasonable assurance" and "materiality" were introduced for the first time (Miller et al., 1993). The extended audit report significantly improved users' perception of the purpose and procedures of the audit as well as the responsibilities of the management and auditors (Gay \& Schelluch, 1993).

In between the big change of audit report content in 1993 (1988 in USA) and the latest big change about expanding audit report content there were changes adopted in 2006 that include a greater discussion on the auditor's responsibilities, a note that the auditor has complied with ethical requirements, a note that the audit evidence obtained is "sufficient and appropriate" to provide a basis for the audit 
opinion and an explanation as to why the auditor evaluates internal control (IAASB, 2003). The main critics about this revised ISA 700 were (Gray et al., 2011): not quantifying level of assurance, materiality and sample sizes and not imply anything about the quality of internal controls nor explicitly say anything about fraud. Similar findings about expectation gap between auditors and users are identified by Asare and Wright (2012) too.

IAASB and AICPA, aware for the existence of the expectation gap between users' understanding and the intended meaning of the standard audit report, have consulted many research papers to identify and evaluate this gap (Gray et al., 2011; Asare \& Wright, 2012; Gold et al., 2012). IAASB exposure draft of ISA 700 released in 2013 initiated many researches about the perception of auditors and other users of new proposed changes. In these studies respondents have supported the IAASB's proposed reforms addressing the expectations, information and communication gaps (Simnett \& Huggins, 2014). Recent studies indicate that participants give attention to the supplementary information presented in the auditor's reports and that the matters mentioned in the report affect the participants' information acquisition in a way that users paid higher attention to the information mentioned in the key audit matters in auditor's report. Furthermore, the number of matters mentioned in the report also has an effect on information acquisition by users (Sirois et al., 2014).

Academics and practitioners are consistent about the increased requirements for audit quality and better communication through the audit report. Triggered by the recent financial crises, new regulation and revised ISA 700 suggest expansion of the audit report in order to decrease the expectation gap which is characterized with continuous existence. The main feature of the new audit report is the introduction of Key Audit Matters where additional information and explanation about the audit process will be included. The very first researches of the effects of the expanded audit report reported that the presence of the quite extensive ISA 700 explanations does not affect the expectation gap (Gold et al., 2012; Boolaky \& Quick, 2016). Only the future will show whether KAM will really be valuable for users of audited financial statements (Kohler et al., 2016).

Auditors following the new audit format should be very careful in choosing what to report in key audit matters since there is evidence that users might to perceive the level of audit quality to be lower especially if there is only one matter mentioned in the auditor's report (Sirois et al., 2014). However, new audit report provides a roadmap that helps users navigate complex financial statements and focus on matters highlighted by the auditor (Sirois et al., 2014) although this could have bias effect on distracting the users' focus from other information presented in financial statements and in a way increase the expectation gap. 
Many of the research studies about extended new audit report also are focused on loan officers. For example, preliminary effects and perceptions are that loan officers have the highest audit expectation gap and place significantly higher value on additional information about the audit process and information about the entity (Litjens et al., 2015).

Regarding the standard audit report that was in force till 2015, the loan officers were better able to identify the responsibilities assumed for the financial statements by both management and the independent auditor (Miller et al., 1993) than from the previous format of the audit report where only the audit opinion was expressed. Furthermore, the modified audit report influenced the loan officers' risk assessment, the interest rate premium and the decision whether or not to grant the loan (Bamber \& Stratton, 1997). The bankers granted loans less often to a company with a modified report than a company with a standard report, and assigned higher interest rate premiums to the former company. Elias and Johnston (2001) in another study investigated whether the explanatory paragraph about going concern has any information content. The results showed that explanatory paragraph indicating going concern uncertainty appeared to convey no additional information content, i.e. bankers receiving modified report did not feel significantly less confident of their decision than those receiving the standard report.

Regarding the audit opinion expressed in audit report, loan officers give no importance to an unqualified audit report if they receive other financial information that is unfavourable towards the client requesting credit, or they are prepared to change a previously favourable attitude when faced with adverse opinions expressed by the auditors (Guiral-Contreras et al., 2007). In later situation, audit report act as 'red flag' that only alerts the loan officers to be more critical and severe in the conditions imposed on a loan when it contradicts the a priori favourable attitude by the loan officers vs. modified or adverse audit report. But there are research studies that do not support the prediction that modified opinions have impact on credit availability possibly because lenders use other kinds of data for their loan decisions (Niemi \& Sundgren, 2012). Other authors go in more details and connect the audit opinion with the internal control opinion describing situation where auditors express unqualified overall opinion but also express adverse internal control opinion that weakens the importance of financial statements and consider the auditors' opinion about internal controls as relevant for their decisions for granting loans (Schneider \& Church, 2008). In other words, even when an auditor provides an unqualified opinion on financial statements, loan officers may view material weaknesses of internal controls and adverse opinion on them as bad news and as a basis for decision to do not grant loan. But very interesting fact about the user of financial statement audit and fact in front of which we cannot slur over is that users of audit report value audit, but do not read entire auditor's report, or even more they cannot assign a measurable value to the audit (Gray et al., 2011). They will more preferably rely on quantitative data or 
independent analysis. In order to address the existent expectation gaps of different users, audit profession should start thinking about innovative and tailor created audit reports that can meet the expectations and needs of different users (Litjens et al., 2015). It means that although additional information are proposed to be included in the new audit report, it is not guarantee that expectation gap will be outmatch.

We decided to conduct a survey study to analyse the perceptions on importance and usage of certain financial information and accounting ratios when deriving at corporate loan decisions. Furthermore, we aim to investigate what importance has for lenders information provided in the independent auditors report according to the old audit report format. The perceptions of lenders as capital providers about the information content of the new audit report is the main purpose of this study, so therefore our survey includes statements on information contents of the new audit report format and asked respondents to evaluate the importance. We were also curious to find whether there is additional information that lenders consider important but not required to be reported under the requirements of ISA's new audit reporting standards. By analysing this, we expect to be able to provide evidence on possible residual audit expectation gap from lenders perspective after implementation of the enhanced audit report in practice.

\section{Research methodology}

The research was carried out with corporate loan officers and heads of corporate loan departments with the banking sector in Macedonia. The online survey was conducted in September 2016 covering in total 114 identified corporate loan officers and heads with 15 banks in the country. Only loan officers and heads involved in disbursement of corporate loans to medium and large companies at least were considered for the sample. The reason is that small and micro companies in Macedonia are not legally required to perform statutory audit on their financial statements, in addition, size thresholds for companies applicable in the country are considered low and there are rare cases of small companies engaging auditors for cost efficiency reasons. The first letter and request to participate in the study was sent early in September 2016, directly through e-mails to all heads of corporate loan departments. In total 18 respondents completed the online survey after the first request, two weeks after the first request a second request was sent and 31 completed online survey questionnaires were considered for the analysis. Table 1 below shows the response statistics for the survey instrument.

Table 1. Survey response statistics

\begin{tabular}{cccccc}
\hline Focus group & Population & Mailed & Incomplete & Responses & Response rate \\
\hline $\begin{array}{c}\text { Corporate loan } \\
\text { officers and heads }\end{array}$ & 114 & 114 & 2 & 31 & $27.2 \%$ \\
\hline
\end{tabular}

Vol. 16, No. 4 
The response rate based on completed surveys without omissions is 27.2 per cent and is considered as satisfactory since online surveys are usually considered inferior to other survey data gathering methods (Owen \& Jones, 1994). The survey questionnaire was composed of four parts, containing statements on the following: Part I: Data on respondents' characteristics (i.e. gender, relevant experience);

Part II: Importance of main statements in companies' annual report;

Part III: Statements on the use and importance of certain accounting ratios in deriving at lending decision;

Part IV: Statements designed to examine the importance of auditors' opinion and other information provided in accordance with the old and new format of the audit report.

The questions were made in closed-ended format in form of a statement that is easier to answer. Likert scale was used for the answer options, ranging from being not important (1) to being very important (5) and accordingly for the extent of reliability in lending decision analysis where the answer options were ranging from never (1) to always considered (5). We conducted focused interviews with four loan officers in the process of constructing the questionnaire in order to achieve reliable understandability for the statements related to the new information that is part or considered desirable in the audit report. In the next section we provide the descriptive statistics for the perceived importance and extent of use of financial information and audit report information by corporate loan officers. We have performed non-parametric Chi-square test in order to test whether there is equal probability for any importance to be given by respondents to the investigated financial or auditor's information, in other words whether our respondents were consistent in assessing the surveyed information as important or not for their lending decisions.

\section{Results}

Most of the respondents were female and had more than 6 years of experience in corporate lending decision making. Cumulatively more than $70 \%$ of the respondents were between 31 and 40 years old (see Table 2). The second part of the questionnaire was designed to investigate perceived importance of the component parts of companies' annual report and the extent of use when evaluating loan proposals. It was expected that loan officers will undoubtedly perceive balance sheet and income statement as very important, but we didn't expected that loan officers will give only medium importance to the Management report. Although, respectively 11 and 10 of the 31 respondents perceived the Management report as considerably important and used very often in their analysis, there were also respondents that viewed the report as not important and never used for their decisions. This contradicts the findings of Berry and Robertson (2006) who provided evidence of increased use of projected financial statements and management accounts in lending decision making. 
The relevance of financial information and contents of the new audit report for lending decisions of commercial banks

Table 2. Respondents' characteristics

\begin{tabular}{lrrlrr}
\hline Gender & \multicolumn{5}{c}{ Experience } \\
\hline \multirow{3}{*}{ Female } & Frequency & Percent & & Frequency & Percent \\
Male & 20 & 64.5 & less than 3 & 2 & 6.5 \\
Total & 11 & 35.5 & $3-5$ & 4 & 12.9 \\
& 31 & 100 & $6-10$ & 11 & 35.5 \\
& & & more than 10 & 14 & 45.2 \\
& & & Total & 31 & 100
\end{tabular}

\begin{tabular}{lrr}
\hline Age & & \\
& Frequency & Percent \\
$23-30$ & 7 & 22.6 \\
$31-35$ & 15 & 48.4 \\
$36-40$ & 8 & 25.8 \\
$40-$ & 1 & 3.2 \\
Total & 31 & 100 \\
\hline
\end{tabular}

In respect of disclosed accounting policies and the notes to the financial statements most of the respondents (18 out of 31 ) considered the information as very important and always used in the analysis, however considerable number of respondents perceived medium or no importance and usability.

Table 3: Descriptive Statistics and Chi square test for the Components of the Annual Report

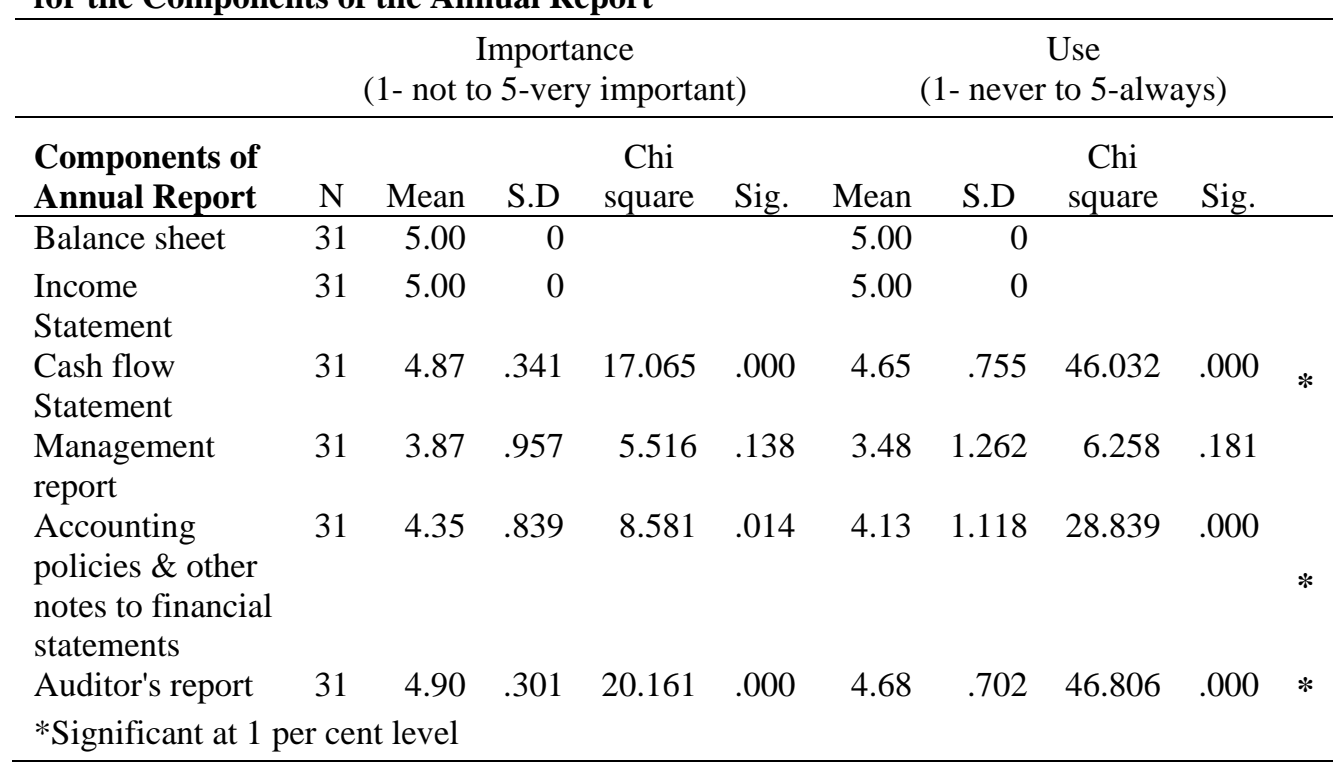

Vol. 16, No. 4 
The third part of the questionnaire focuses on perceived importance of selected accounting ratios and suggested type of analysis that uses historical or prospective accounting information. The descriptive statistics and respective Chi-square test results are presented in table 4 below. We conclude that respondents were consistent in evaluating the high importance and usage of liquidity and financial stability ratios. However, respondents were not consistent when they evaluated the importance of projected figures for company's profitability, although this information is very often used in lending decision making. Similar perceptions loan officers have regarding the importance of historical operating cash flow information. Most of the respondents considered it little less important than other surveyed information (mean of 4.41 for importance and 4.28 for use).

Table 4: Descriptive Statistics and Chi square test for Accounting information and Ratios

Importance Use

(1- not to 5-very important) (1- never to 5-always)

\begin{tabular}{|c|c|c|c|c|c|c|c|c|c|c|}
\hline Ratios & $\mathrm{N}$ & Mean & S.D. & $\begin{array}{c}\text { Chi } \\
\text { square }\end{array}$ & Sig. & Mean & S.D. & $\begin{array}{c}\text { Chi } \\
\text { square }\end{array}$ & Sig. & \\
\hline \multicolumn{11}{|l|}{ Liquiduty } \\
\hline Current ratio & 31 & 4.68 & .653 & 27.161 & .000 & 4.81 & .543 & 40.323 & .000 & $*$ \\
\hline Quick ratio & 31 & 4.61 & .667 & 20.194 & .000 & 4.71 & .643 & 31.326 & .000 & $*$ \\
\hline $\begin{array}{l}\text { Working capital } \\
\text { trend analysis }\end{array}$ & 31 & 4.45 & .810 & 25.129 & .000 & 4.32 & 1.045 & 35.290 & .000 & * \\
\hline \multicolumn{10}{|l|}{$\begin{array}{l}\text { Financial } \\
\text { stability }\end{array}$} & \\
\hline Interest coverage & 31 & 4.84 & .374 & 14.226 & .000 & 4.81 & .543 & 40.323 & .000 & $*$ \\
\hline Total debt/equity & 31 & 4.87 & .428 & 45.355 & .000 & 4.84 & .583 & 45.355 & .000 & $*$ \\
\hline $\begin{array}{l}\text { Interest bearing } \\
\text { debt/equity }\end{array}$ & 31 & 4.45 & .888 & 27.968 & .000 & 4.35 & 1.082 & 40.774 & .000 & $*$ \\
\hline $\begin{array}{l}\text { Long-term debt } \\
\text { maturity analysis }\end{array}$ & 31 & 4.74 & .445 & 7.258 & .007 & 4.52 & .811 & 20.194 & .000 & $*$ \\
\hline \multicolumn{10}{|l|}{ Profitability } & $*$ \\
\hline $\begin{array}{l}\text { Profit margins } \\
\text { (i.e. gross, oper., } \\
\text { net) }\end{array}$ & 31 & 4.90 & .301 & 20.161 & .000 & 4.97 & .180 & 27.129 & .000 & $*$ \\
\hline $\begin{array}{l}\text { Historical trends } \\
\text { in profitability }\end{array}$ & 31 & 4.68 & .599 & 24.065 & .000 & 4.71 & .588 & 27.548 & .000 & $*$ \\
\hline $\begin{array}{l}\text { Projected future } \\
\text { profitability }\end{array}$ & 31 & 4.35 & .755 & 5.871 & .053 & 4.16 & 1.068 & 17.387 & .001 & $*$ \\
\hline \multicolumn{10}{|l|}{ Cash flows } & * \\
\hline $\begin{array}{l}\text { Planned cash } \\
\text { flows }\end{array}$ & 31 & 4.84 & .454 & 40.516 & .000 & 4.65 & .755 & 46.032 & .000 & $*$ \\
\hline
\end{tabular}


The relevance of financial information and contents of the new audit report for lending decisions of commercial banks

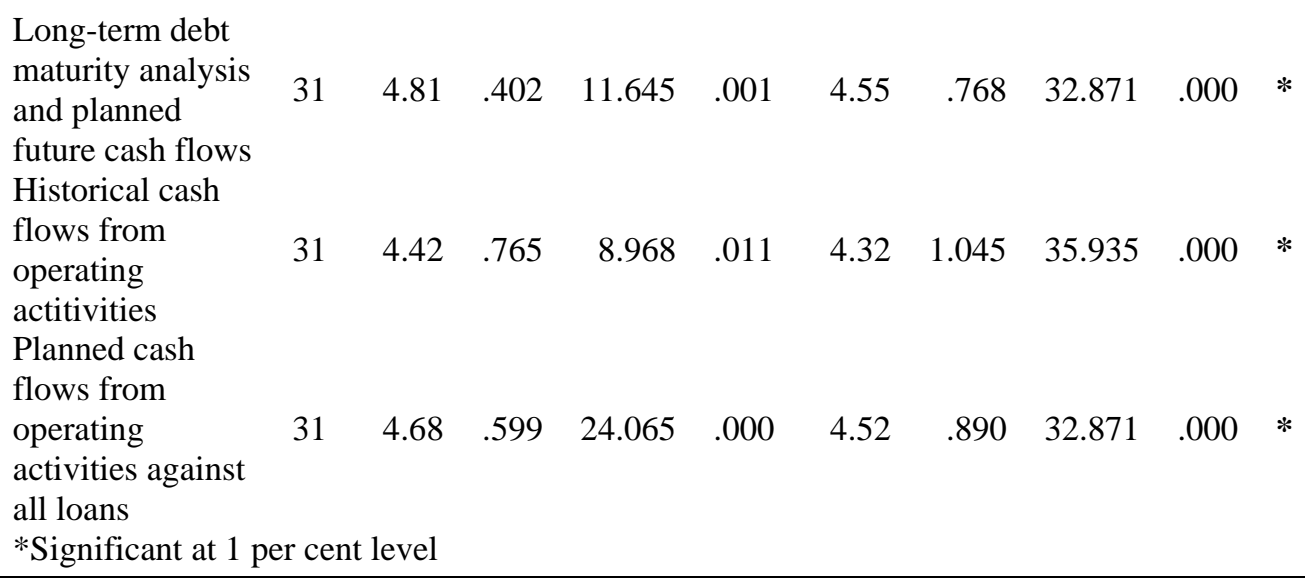

Our research shows interesting results for the primary focus of the study, the importance of information contained in the audit report for lending decisions as perceived by corporate loan officers and heads of corporate loan departments. We also wanted to assess the views on newly required information according to new and revised ISA's on audit reporting (Tables 5 and 6). In order to obtain data on lenders' perceptions whether the New Audit Report will satisfy needs of creditors in respect of audit information, we deliberately introduced statements for additional information that could be considered important for creditors but is not required under new ISA's on audit reporting (Table 6).

Corporate lenders rated the importance of main statements in the standard audit report as very high, and these perceptions were consistently shared among all 31 respondents (from 22 to 28 on 6 different statements). This is consistent with the findings of Epstein and Pava (1992), but contradicts the findings of Berry and Robertson (2006) and Bartlett and Chandler(1997) who provided evidence of decrease importance of the audit report.

Table 5: Descriptive Statistics and Chi square test-Audit Report in the old format

\begin{tabular}{|c|c|c|c|c|c|c|}
\hline \multirow[b]{2}{*}{ Statements } & \multicolumn{6}{|c|}{$\begin{array}{c}\text { Importance } \\
\text { (1- not to 5-very important) }\end{array}$} \\
\hline & $\mathrm{N}$ & $\begin{array}{c}\text { Mea } \\
\mathrm{n}\end{array}$ & $\begin{array}{c}\text { S.D } \\
.\end{array}$ & $\begin{array}{c}\text { Chi } \\
\text { square }\end{array}$ & Sig. & \\
\hline $\begin{array}{l}\text { The Auditor stated he is independent or } \\
\text { highlighted conditions that threat his } \\
\text { independence. }\end{array}$ & $\begin{array}{l}3 \\
1\end{array}$ & 4.71 & .643 & $\begin{array}{r}28.32 \\
3\end{array}$ & $\begin{array}{r}.00 \\
0\end{array}$ & $*$ \\
\hline $\begin{array}{l}\text { The Auditor expressed an opinion that financial } \\
\text { statements give true and fair view of financial } \\
\text { condition and results. }\end{array}$ & $\begin{array}{l}3 \\
1\end{array}$ & 4.65 & .608 & $\begin{array}{r}20.96 \\
8\end{array}$ & $\begin{array}{r}.00 \\
0\end{array}$ & $*$ \\
\hline
\end{tabular}


The Auditor has identified in his opinion existence of material misstaments in the financial statements The Auditor expressed unqualified opinion, however emphasized on the going concern of the entity.

The Auditor could not perform appropriate procedures and has given a disclaimer.

The Auditor expressed opinion that financial statements do not give a true and fair view of financial condition and results of the entity.

\begin{tabular}{|c|c|c|c|c|}
\hline & 4.90 & .301 & $\begin{array}{r}20.16 \\
1\end{array}$ & $\begin{array}{r}.00 \\
0\end{array}$ \\
\hline & 4.65 & .755 & $\begin{array}{r}46.03 \\
2\end{array}$ & $\begin{array}{r}.00 \\
0\end{array}$ \\
\hline & 4.61 & .844 & $\begin{array}{r}46.03 \\
2\end{array}$ & $\begin{array}{r}.00 \\
0\end{array}$ \\
\hline & 4.84 & .523 & $\begin{array}{r}45.35 \\
5\end{array}$ & $\begin{array}{r}.00 \\
0\end{array}$ \\
\hline
\end{tabular}

*Significant at 1 per cent level

Interestingly, our analysis showed the highest mean result (4.9 in table5) for the statement "The Auditor has identified in his opinion existence of material misstatements in the financial statement". This can be interpreted that corporate lenders expect to see qualified audit reports for certain financial statements' positions for which material misstatement have been identified. In that sense the audit report is more valuable to lenders and financial information provided in financial statements is more credible for usage in lending decisions.

We continue our analysis in respect of perceived importance of new information content of the Audit Report as required by new and revised ISA's on audit reporting. As shown in table 6 below, loan officers perceived information related to going concern assumption and any material uncertainties for the assumption as highly important for lending decision process, and they were consistent in their evaluation. This contradicts the findings of Elias and Johnston (2001) who found no evidence of information content differences attributable to auditors' explanatory paragraph for going concern in addition to notes disclosure.

Table 6: Descriptive Statistics and Chi square test for the New Audit Report

\begin{tabular}{|c|c|c|c|c|c|}
\hline \multirow[b]{2}{*}{ Information content } & \multicolumn{5}{|c|}{$\begin{array}{c}\text { Importance } \\
\text { (1- not to 5-very important) }\end{array}$} \\
\hline & Mean & S.D. & $\begin{array}{c}\text { Chi } \\
\text { square }\end{array}$ & Sig. & \\
\hline \multicolumn{6}{|l|}{ Information required by new ISA's on audit reporting } \\
\hline $\begin{array}{l}\text { Description of procedures used by auditor to assess } \\
\text { whether the entity is a going concern. }\end{array}$ & 4.13 & .957 & 13.258 & .004 & * \\
\hline $\begin{array}{l}\text { Separate information section whether the entity is } \\
\text { going concern when material uncertainty exists. }\end{array}$ & 4.58 & .720 & 19.806 & .000 & * \\
\hline $\begin{array}{l}\text { Information on key matters considered during the } \\
\text { audit related to most risky and complex areas that can } \\
\text { result in material misstatements in financial }\end{array}$ & 4.65 & .798 & 51.452 & .000 & * \\
\hline
\end{tabular}


The relevance of financial information and contents of the new audit report for lending decisions of commercial banks

\begin{tabular}{|c|c|c|c|c|c|}
\hline \multirow[b]{2}{*}{ Information content } & \multicolumn{5}{|c|}{$\begin{array}{c}\text { Importance } \\
\text { (1- not to 5-very important) }\end{array}$} \\
\hline & Mean & S.D. & $\begin{array}{c}\text { Chi } \\
\text { square }\end{array}$ & Sig. & \\
\hline $\begin{array}{l}\text { Information how the auditor addressed key audit } \\
\text { matters. }\end{array}$ & 3.97 & 1.048 & 6.548 & .088 & \\
\hline $\begin{array}{l}\text { The name of the partner of the audit firm responsible } \\
\text { for the audit engagement. }\end{array}$ & 3.55 & 1.261 & 6.258 & .181 & \\
\hline $\begin{array}{l}\text { Affirmative statement about the auditor's } \\
\text { independence and fulfillment of relevant ethical } \\
\text { responsibilities }\end{array}$ & 3.77 & 1.359 & 18.839 & .001 & * \\
\hline $\begin{array}{l}\text { Information disclosed for the level of materiality used } \\
\text { during the audit. }\end{array}$ & 3.77 & 1.087 & 1.903 & .593 & \\
\hline $\begin{array}{l}\text { Description of auditor's procedures related to the } \\
\text { risk of fraud in the financial statements. }\end{array}$ & 4.32 & .909 & 20.226 & .000 & * \\
\hline \multicolumn{6}{|l|}{$\begin{array}{l}\text { Information not required by new ISA's on audit } \\
\text { reporting }\end{array}$} \\
\hline $\begin{array}{l}\text { Information in the Audit report for identified } \\
\text { misstatements been corrected and misstatements for } \\
\text { which financial statements are not corrected }\end{array}$ & 4.52 & .811 & 31.839 & .000 & * \\
\hline $\begin{array}{l}\text { Information on effectiveness of internal controls } \\
\text { related to the process of producing financial } \\
\text { information. }\end{array}$ & 4.10 & .978 & 14.290 & .003 & * \\
\hline $\begin{array}{l}\text { Information on effectiveness of internal controls } \\
\text { related to the overall operations of the entity. }\end{array}$ & 4.13 & .922 & 10.935 & .012 & * \\
\hline $\begin{array}{l}\text { Information on entity's breach of covenant } \\
\text { provisions in loan agreements related to required } \\
\text { financial results and condition. } \\
\text { *Significant at } 1 \text { per cent level }\end{array}$ & 4.61 & .803 & 45.774 & .000 & * \\
\hline
\end{tabular}

Also, loan officers considered information on audit procedures related to risk of fraud in financial statements and disclosed information on key matters for auditors as very important. Key audit matters disclosed in the audit report were also perceived as very important and this is consistent with the findings of Sirois $e t$ al. (2014) and opposite to the findings of Boolaky and Quick (2016). However, less important is the information for the name of the audit partner in the engagement and the level of materiality used. Different loan officers were also inconsistent when evaluating the importance of this type of information disclosed in the audit report (chi-square at $1 \%$ significance level).

Concerning information that is not required to be disclosed by the auditor in the audit report prepared according to the requirements of new and revised ISA's on audit reporting, loan officers gave consistently high importance to information 
related to identified misstatements for which financial statement were corrected or not corrected (mean 4.52). Also, considerably high importance is perceived for disclosed information on entity's breach of debt covenants related to required financial condition and performance. Loan officers were consistent when evaluating information on internal controls related to financial reporting as important but less important than above mentioned information (mean 4.10). Considering information on internal controls related to the overall operations of the entity, respondents gave inconsistent assessments for the importance resulting in a mean result for high importance (mean 4.13).

\section{Conclusion}

Based on the results from the survey study discussed, we can conclude that published accounting information and traditional accounting ratios remain very important for lenders when arriving at lending decisions. Management information on projected profitability or the Management Report part of the Annual Report is less important when bank loan officers evaluate loan proposals of their clients, which contradicts the findings of recent studies on usefulness of financial information to lenders (Berry \& Robertson, 2006). The balance sheet and income statement are considered more important than information on accounting policies used or other information provided in the notes to the financial statements.

Lenders perceive the standard audit report as valuable source of information for lending decisions, regardless of the type of the auditor's opinion. However, lenders are keener to see qualifications in the auditors' reports regarding material misstatements in the financial statements, finding supported in other studies as well (Guiral-Contreras et al., 2007). Most of the incremental information in the New Auditor's Report is perceived as very important, such as information on key matters for the auditor, existence of material uncertainty and auditor's judgement for the going concern and auditor's procedures related to risk of fraud in the financial statements. However, there is still important information that could be provided by auditors, as per lenders perceptions, but disclosure of such information is not required under ISA's new and revised audit reporting standards effective from 2016. Lenders expect to see information on effectiveness of internal controls related to financial reporting. In other jurisdictions, such as US lenders judgments have been also affected by auditor's report on effectiveness of internal controls (Schneider \& Church, 2008). Also, information on identified misstatements during the audit for which financial statements were corrected, as well as misstatements for which statements are not being corrected is considered very important. As usually evidenced by researchers of bankers' preferences for financial and audit information, details on eventual breach of debt covenants provided in the audit report are very important. 
Similarly to other survey studies, this study has limitations deriving from the method employed in terms of possible non-response bias (Sax et al., 2003). Also, on-line surveys do not provide large samples in comparison to other ways of gathering survey data. Although we have taken appropriate steps while constructing questions and statements to measure the variables, statements bear certain degree of subjectivity. The study does not go into indebt analysis of lenders understanding of certain type of information found or to be found into auditor's report, nor their ability to use and interpret such information in order to improve lending decisions. Respondents of the study have no practical experience with the New Auditor's Report, so future survey research performed on the same focus group could provide evidence of different views for the importance of incremental information provided in the New Auditor's report.

Nevertheless, the study contributes the limited literature so far investigating the impact of the information contained in the New Auditor's Report on lenders decision making and general perceptions in the public about the quality of the audit report of the future and audit expectation gap.

Acknowledgements: the authors thank the reviewer and participants at the $12^{\text {th }}$ Accounting and Management Information Systems (AMIS) International Conference held at the Bucharest University of Economic Studies (June 7-8 2017) and the editor of the Journal of Accounting and Management Information Systems for guidance and support in revising the paper.

\section{References}

Anderson, R. \& Epstein, M. (1995) "The usefulness of annual reports", Australian Accountant, Issue April: 25-28

Asare, S. \& Wright, A. (2012) 'Investors', auditors', and lenders' understanding of the message conveyed by the standard audit report on the financial statement", Accounting Horizons, vol.26(2): 193-217

Bamber, E. M. \& Stratton, R. A. (1997) "The information content of the uncertainty-modified audit report: evidence from bank loan officers", Accounting Horizons, vol.11(2): 1-11

Bartlett, S. \& Chandler, R. (1997) "The corporate report and the private shareholder: Lee and Tweedie twenty years on", British Accounting Review, Issue September: 245-261

Berry, A. \& Robertson, J. (2006) "Overseas bankers in the UK and their use of information for making lending decisions: Changes from 1985", British Accounting Review, vol. 38: 175-191 
Boolaky, P. K. \& Quick, R. (2016) "Bank directors' perceptions of expanded auditor's report", International Journal of Auditing, vol. 20: 158-174

Elias, R. Z. \& Johnston, J. G. (2001) "Is there incremental information content in the going concern explanatory paragraph?", Advances in Accounting, vol. 18: $105-117$

Epstein, M. \& Pava, M. (1992) "How useful is the statement of cash flow", Management Accounting, vol.74 (1): 52-55

Gay, G. \& Schelluch, P. (1993) "The effect of the longform audit report on users' perceptions of the auditor's role", Australian Accounting Review, vol.3(2): 211

Gold, A., Gronewold, U. \& Pott, C. (2012) "The ISA 700 Auditor's report and the audit expectation gap: do explanations matter?", International Journal of Auditing, vol. 16: 286-307

Gray, G., Turner, J., Coram, P. \& Mock, T. J. (2011) "Perceptions and misperceptions regarding the unqualified auditor's report by financial statement preparers, users and auditors", Accounting Horizons, vol. 25(4): 659-684

Guiral-Contreras, A., Gonzalo-Angulo, J. \& Rodgers, W. (2007) "Information content and recency effect of the audit report in loan rating decisions", Accounting and Finance, vol. 47: 285-304

Hines, R. (1982) "The usefulness of annual reports: the anomaly between the efficient market hypothesis and shareholder surveys", Accounting and Business Research, Issue Autumn: 296-309

IAASB (2003) "The independent auditor's report on a complete set of general purpose financial statements", New York: IAASB.

Kohler, A. G., Quick, R. \& Willekens, M. (2016) "The new European audit regulation arena: discussion of new rules and ideas for future research", International Journal of Auditing, vol.20: 211-214

Litjens, R., Buuren, J. \& Vergoossen, R. (2015) “Addressing information needs to reduce the audit expectation gap: evidence from Dutch bankers, audited companies and auditors", International Journal of Auditing, vol.19: 267-281

Masters, C. (2015) ACCA [Online] Available at: http://www.accaglobal.com /pk/en/student/sa/news/the-audit-report-evolution.html [Accessed $15 \quad 11$ 2016].

Miller, J. R., Reed, S. \& Strawser, R. (1993) "Bank loan officers' perceptions of the new audit report", Accounting Horizons, vol.7(1): 39-52

Nair, R. \& Rittenberg, L. (1987) "Messages perceived from audit, review and compilation reports: extension to more diverse groups", Auditing: A Journal of Practice and Theory, vol. 7 (Fall): 15-38

Niemi, L. \& Sundgren, S. (2012) "Are modified audit opinions related to the availability of credit?: Evidence from Finnish SMEs", European Accounting Review, vol.21(4): 767-796

Owen, F. \& Jones, R. (1994) Statistics, London: Pitman 
The relevance of financial information and contents of the new audit report for lending decisions of commercial banks

Robertson, J. C. (1988) “Analysts' reactions to auditors' messages in qualified reports", Accounting Horizons, vol.2: 82-89

Sax, L.J., Gilmartin, S.K. \& Bryant, A.N. (2003) "Assessing response rates and nonresponse bias in web and paper surveys", Research in Higher Education, vol.44 (4): 409-432

Schneider, A. \& Church, B. (2008) “The effect of auditors' internal control opinions on loan decisions", Journal of Accounting and Public Policy, vol.27: $1-18$

Simnett, R. \& Huggins, A. (2014) "Enhancing the auditor's report: to what extend is there support for the IAASB's proposed changes?", Accounting Horizons, vol.28(4): 719-747

Sirois, L., Bedard, J. \& Bera, P. (2014) "The informational value of key audit matters in the auditor's report: evidence from an Eye-tracking study", Available at SSRN 2469905 